\title{
How is Uniqueness Understood among International Students in Turkey? An Interpretative Phenomenological Analysis
}

\author{
Türkiye'de Uluslararası Öğrenciler Biricikliği Nasıl Anlamaktadır? \\ Yorumlayıcı Bir Fenomenolojik Analiz
}

\section{Sıla DEMIR * Müjde KOCA-ATABEY * Bengi ÖNER-ÖZKAN ***}

\begin{abstract}
Although the literature on uniqueness has emphasized that it is unique to the Western culture, recent studies have indicated that the need for uniqueness is getting more familiar to the Eastern culture. The current study aimed to get a deeper understanding of uniqueness by investigating the concept among international students. Primarily, the perception and evaluation of uniqueness by participants from other cultures is investigated. The data were collected from seven international undergraduate students studying in Turkey. The interpretative phenomenological analysis (IPA) was used to analyze the participant accounts. The IPA is a qualitative analysis tool that aimed to investigate the meanings of particular experiences. The results revealed that there were three final themes: "Who is unique? Extraordinary, intelligent and different" "Ordinary: You are safe but routine" and "Turkey and home country: We have Nelson Mandela; you have Mustafa Kemal Atatürk". It was indicated that uniqueness is seen as exceptional and distinctive, but it is something to be achieved in time. On the other hand, ordinary people were criticized for conforming to the norms, besides the advantage of a comfortable life. The results were discussed in relation to the experiences of international students and the differences between cultures.
\end{abstract}

Keywords: Uniqueness, Ordinariness, International Students, Cross-Cultural Comparisons, Interpretative Phenomenological Analysis

$\ddot{O}_{z:}$ Biriciklik konusunda yapılan çalışmalar, genel olarak biriciklik olgusunun Batı kültürlerinde yaygın olduğunu gösterse de son yıllarda Doğu kültürlerinde de biriciklik ihtiyacının yaygınlaştı̆̆ görülmektedir. Bu nedenle, bu çalışma, biriciklik kavramının uluslararası öğrenciler tarafından nasıl anlaşıldığını araştırarak konuya dair daha derinlemesine bilgi elde etmeyi amaçlamaktadır. Temel olarak, biricikliğin başka kültürlerden katılımcılar tarafından nasıl algılandığı ve değerlendirildiği incelenmektedir. Veri, Türkiye'de okuyan yedi uluslararası lisans öğrencisinden toplanmış ve yorumlayıcı fenomenolojik analiz (YFA) ile incelenmiş̧ir. YFA, belirli deneyimlerin anlamlarını araştırmayı amaçlayan nitel bir analiz aracıdır. Sonuçlar, katılımcıların yanıtlarında üç tema olduğunu ortaya çıkardı: "Kim benzersiz? Olağanüstü, zeki ve farklı" "Siradan: Güvendesin ama rutinsin" ve "Türkiye ve memleket: Bizim Nelson Mandela'mız var; sizin Mustafa Kemal Atatürk’ünüz”. Katılımcılar tarafindan biriciklik istisnai ve ayırt edici göründüğü, ancak zaman içinde başarılması gereken bir şey olduğu belirtildi. Öte yandan, sıradan insanlar rahat bir yaşamın avantajını yaşamanın yanı sıra normlara uydukları için eleştirilmişlerdir. Sonuçlar, uluslararası öğrencilerin deneyimleri ve kültürler arasındaki farklılıklar ile ilgili olarak tartışılmışıtır.

Anahtar sözcükler: Biriciklik, Sıradanlık, Uluslararası Öğrenciler, Kültürlerarası Karşılaştırma, Yorumlayıc1 Fenomenolojik Analiz

\footnotetext{
* Asst. Prof., Antalya Bilim University, School of Business and Social Sciences, Department of Psychology, Antalya. sila.demir@antalya.edu.tr, https://orcid.org/0000-0002-6121-6046

** Assoc. Prof., Department of Psychology, Faculty of Economics, Administrative, and Social Sciences, Ankara Medipol University, cemilemujde.atabey@ankaramedipol.edu.tr https://orcid.org/0000-0001-8782-2960

*** Prof., Middle East Technical University, Faculty of Arts and Sciences, Department of Psychology, bengi@metu.edu.tr https://orcid.org/0000-0002-9050-2818
} 
People's tendency to achieve and maintain a moderate level of uniqueness has been studied widely within psychology and related fields. Snyder and Fromkin departed from the idea that people often define themselves with specialness (Snyder 1992). They suggested that the need to be different from others varies from person to person (Snyder \& Fromkin 1977). Many studies on uniqueness have been published after they proposed the uniqueness theory $(1977 ; 1980)$. Some of these studies helped uncover the individual differences associated with the need for uniqueness. For instance, while higher extraversion and openness were related with a higher need for uniqueness, higher neuroticism and agreeableness were related with a lower need for uniqueness (Schumpe et al. 2016). Many other studies have been devoted to understanding the cultural underpinnings and differences in the level and expression of this need (e.g., Markus \& Kitayama 1991; Kim \& Sherman 2007; Twenge et al. 2010).

Although a considerable literature was focused on how individuals strive to achieve and sustain uniqueness, no study has been devoted to deeply understand how people perceive uniqueness, as it can be in a qualitative study to the best of our knowledge. Moreover, crosscultural studies of uniqueness have reached up to a couple of counties to compare the similarities and differences of uniqueness perceptions by people from different cultural backgrounds (e.g., United States-Japan comparison, Kinias et al. 2014; Takemura, 2014; and East Asian-European American comparison, Markus \& Kitayama 1991; Heine \& Lehman 1997). Bearing those gaps of the literature in mind, in the current study, we have focused on the perception and evaluation of uniqueness by international students, how they perceive their own uniqueness, and how they compare their home country with Turkey. We employed the interpretative phenomenological analysis to investigate this issue thoroughly.

\section{Uniqueness}

Some researchers had suggested the need to explore uniqueness within conformity studies way before Snyder and Fromkin (1977) made the distinction between abnormal deviance and positive uniqueness (e.g., Deutsch \& Krauss 1965). These researchers also pointed out that even in the famous study of Asch (1951), two-thirds of the participants did not conform. Moreover, when individuals perceive too much similarity, they physically distance themselves from others (Snyder \& Endelman 1979), change attitudes towards the opposite of the other people (Weir 1971), and conform less (Imhoff \& Erb 2009).

Relying on this literature, Snyder and Fromkin (1977) suggested that some situational factors affect individuals' uniqueness needs. At different points in time, the same people might perceive the same conditions as of different levels of similarity and difference. Furthermore, even the same perceptions of similarity can trigger different levels of strives for uniqueness for each. Therefore, there should also be dispositional differences in peoples' motivation to strive for uniqueness. Depending on this rationale, at the center of the uniqueness theory is that everyone needs to be unique, but there are individual differences determining the level of this need (Snyder 1992).

\section{Uniqueness in the cross-cultural domain}

In addition to dispositional differences, culture's systematic impact on the level of need for uniqueness is also investigated. These studies focusing on the differences between cultures, by nature, hold the implicit assumption that within-culture variation would not be high. The literature indicates that independence, authenticity, and freedom are emphasized in Western society (see Triandis 2001). Furthermore, according to Vignoles and colleagues (2016), difference-similarity is one of the seven dimensions of individualism, measured with items such as "I am a unique individual". Parallel to that, their child-raising styles include one's own 
decision making without being influenced by other people, and being responsible for their own choices, in contrast to Eastern society (Markus et al. 1997).

Similarly, two studies demonstrated that Japanese and Korean participants score lower on the need for uniqueness compared to Canadian and German participants, respectively (Tafarodi et al. 2004; also see Schumpe et al. 2016). Moreover, uniqueness is valued as an expression of individuality. For instance, people who are high in uniqueness need are evaluated more favorably in California in the US, compared to Kansai in Japan (Kinias et al. 2014; Takemura 2014).

Consequently, individuals' self-perceptions regarding their uniqueness or ordinariness seem to be influenced by the culture. For example, while the East Asians emphasize their ordinariness frequently, European Americans prefer to point to their uniqueness (Heine \& Lehman 1997; Markus \& Kitayama, 1991). Manifestations of these preferences are evident in experimental studies, too (e.g., Kim \& Markus 1999; Kim \& Sherman 2008). However, Yamagishi and colleagues argue that these are not preferences, but strategies individuals embrace depending on their many experiences of being rewarded or punished for their behaviors as in an operant conditioning approach (Yamagishi et al. 2008).

Nevertheless, contrary to the massive support from social psychology literature for uniqueness in the Western societies, it is noteworthy that the striking conformity and obedience studies of Asch (1951) and Milgram (1963) were conducted in the United States. In this case, conformity has been explained as self-protection from an evolutionary perspective (Kenrick et al. 2003; Griskevicius et al. 2006). Furthermore, recent studies started to reveal a strong need for uniqueness for Eastern cultures as well. For example, Bian and Forsythe (2012) found a higher need for uniqueness among consumers in China, compared to those in the US, manifested by, in another study, buying certain products as a way of displaying a distinct social position (Sun et al. 2015). A more recent study argues an increase in the need for uniqueness in China by pointing out inter-generational differences and name preferences of the parents for their babies (Cai et al. 2018).

In addition to these cross-cultural differences and similarities, inquiries on within-culture variations of perceptions of uniqueness revealed that social status variables of gender and occupational status, and life context (professional, friends, and family) determine personal uniqueness (Causse \& Felonneau 2014). These findings challenged the within-culture homogeneity assumptions of the cross-cultural research on uniqueness.

\section{Present study}

The current study was derived from both the inconsistency in the literature on whether uniqueness being uniquely Western or a universal need and the need for a thorough understanding of perceptions of uniqueness by people from various cultural backgrounds. Understanding different perceptions of uniqueness become of more importance as international contact increases worldwide. The participants are international students who temporarily experience a different culture for a specific reason, i.e., education.

The increasing number of international students is the norm rather than an exception. Bilecen (2013) mentions that international doctoral students enjoy a different culture, lifestyle, and working environment. On the other hand, besides the common characteristics of being welleducated and open to experiencing a new culture (Furnham \& Bocher 1982), the term 'international student' does not refer to a homogenous group (Tran \& Pham 2016), and being an international student is not a comfortable experience. Thus, international students might need extra time and effort in their studies (Angelova \& Riazantseva 1999). An Australian study points to loneliness due to the absence of familiar cultural and linguistic surroundings as an 
important problem for international students (Sawir et al. 2008). Also, Tarry (2011) suggests that Thai students studying in the United Kingdom have to solve various social and cultural tensions. Researchers suggest that a preparation program for the international students in the home country and an orientation program in the host country might reduce the psychological distress they experience (Çetinkaya-Yıldiz et al. 2011). Furthermore, several studies indicate that a high need for uniqueness might facilitate better adaptation to the new, mobile, and open social environment (Takemura, 2014; Debrosse et al. 2015). Therefore, the present study is conducted to explore international students' uniqueness expressions from a qualitative perspective.

\section{Method}

\section{Participants}

Participants were seven undergraduate international students from a middle-sized foundation university from Ankara, Turkey. The medium of instruction in this university was English. An international student is defined as a student who was born in another country or lived abroad for most of their life, and whose main aim of coming to the country was getting a degree in a Turkish institution. In the current study, the participants were referred by pseudonyms representing their country of origin and native language. The demographics are provided in Table 1. One participant has Turkish origins but was regarded as an international student since she spent all her life in another country and came to Turkey for undergraduate education.

Table 1. Demographics of the Participants.

\begin{tabular}{|c|c|c|c|c|c|}
\hline Pseudonym & Age & Sex & Department & Country & Native Language \\
\hline Eline & 19 & Female & Psychology & Netherlands & Dutch/German \\
\hline Alison & 19 & Female & Psychology & United States & English \\
\hline Minenhle & 21 & Female & Psychology & South Africa & IsiXhosa \\
\hline Badu & 22 & Male & $\begin{array}{l}\text { International } \\
\text { Relations }\end{array}$ & Ghana & English \\
\hline Luana & 19 & Female & Psychology & Albania & Albanian \\
\hline Qumar & 23 & Male & $\begin{array}{l}\text { Business } \\
\text { Administration }\end{array}$ & $\begin{array}{l}\text { Guinea- } \\
\text { Bissau }\end{array}$ & Portuguese \\
\hline Zehra & 18 & Female & $\begin{array}{l}\text { International } \\
\text { Relations }\end{array}$ & Netherlands & Turkish/Dutch \\
\hline
\end{tabular}

\section{Procedure and analysis}

After obtaining ethical approval, the participants were recruited by the ads posted in the psychology department in 2016 Spring semester. Participation was voluntary in return for extra course credit. For the participants who are not international students or who did not want to attend this study, alternative arrangements (i.e., summarizing a research article) were made to provide the extra course credit. The following four open-ended questions were asked to the participants in a paper-and-pencil format: (1) What kind of a person would you call 'unique?' (2) What kind of person would you call 'ordinary?' (3) Do you consider yourself to be unique? Why/Why not? (4) How similar or different the perception of "uniqueness" and "ordinariness" between your home country and Turkey? Following these open-ended questions, the participants filled out a short demographic information sheet. The data collection for each participant took approximately $35-45$ minutes.

The interpretative phenomenological analysis (IPA) was selected to analyze the participant accounts. The IPA deals with the personal experiences and the participants' evaluations of these 
experiences. Initially, the IPA was used within the health psychology domain. However, currently, the corpus of the IPA studies is much broader and more varied than before (Smith \& Osborn 2003; Smith 2011). These studies include the strike experiences of a firefighter (Brunsden \& Hill 2009), flow experience among graduate students (Koca-Atabey 2007), or the learning experience of entrepreneurs after a venture failure (Cope 2011). The IPA might also be used to analyze a specific experience, such as the meaning of delusional experiences among patients with Parkinson's disease (Todd et al. 2010), or more general experience, such as being a non-drinking undergraduate student (Conroy \& de Visser 2014). Although semi-structured interviews are the most common tool for the IPA, they are only exemplary. Personal accounts and diaries might also be a source of analysis for the IPA (Smith \& Osborn 2003). For instance, Larkin and Griffiths (2002) analyzed observational data collected at a treatment center via the IPA. It was also used to analyze video recordings (Lee \& Skewes-McFerran 2015; O'Toole 2013), data that arose from focus groups (Palmer et al. 2010), or the accounts of film characteristics (Koca-Atabey 2016). Smith (2011) discussed some principles, such as being clear, coherent, and transparent for a 'good' IPA study. In the present study, the participant accounts were analyzed according to these guidelines.

Smith and Osborn (2003) revealed that there is no single way to analyze findings within the IPA. The researchers are free to explore their way. For this specific piece, we read all transcripts several times and indicated interesting and significant points. Afterward, we defined the emergent themes. In the last phase of the analysis, we decided upon the subordinate and superordinate themes.

\title{
Findings
}

The IPA revealed three final themes: "Who is unique? Extraordinary, intelligent and different", "Ordinary: You are safe but routine" and "Turkey and home country: We have Nelson Mandela; you have Mustafa Kemal Atatürk".

\section{Who is unique? Extraordinary, intelligent, and different}

Below are some quotes from participants describing the unique person; uniqueness was regarded as a positive quality, which specifies the person's distinctiveness.

\begin{abstract}
A unique person is one with extraordinary qualities. A quality that majority of the people do not have. For example, a person with a high-level IQ, an artist, a painter, a poet, a singer, etc. ... a quality that majority of the people do not have (Badu, male, 22 years old).

A unique individual is someone who isn't self-absorbed, they put others before them, they are loving and caring because they give love even to those who would be considered as unlovable or give care to those whom others don't care about. They are thoughtful, intelligent (Minenhle, female, 21 years old).
\end{abstract}

The sign of this character would be when everybody goes left; the unique person will go right. Doing the opposite of what people do (not all the time) and doing the same job in a different way compared to the ordinaries (Zehra, female, 18 years old).

In my opinion, someone who is unique is the person who can express his feelings and beliefs without any fear. Someone who is different from the whole "crowd." ... To follow your dreams, you must be unique. You may get some criticism (Eline, female, 19 years old).

The superordinate theme 'Who is unique? Extraordinary, intelligent and different' was further divided into a sub-theme that refers to self-perceptions:

\section{Am I unique? Don't know, not yet}

Actually, I couldn't tell you whether I am unique or not. But since my friends tell me that I 
am kind of different in my behaviours and speech, and from the way of my finding new and different solutions, I could tell you that I am a bit unique person (Zehra, female, 18 years old).

I am only 19 years old, so I can't say much about life, but I consider myself ordinary and lucky. Until now, I haven't done something extraordinary. I live a normal life in a normal family. I don't excel in anything, and I am not always the best at anything (Luana, female 19 years old).

\section{Ordinary: You are safe but routine.}

The quotes describing "an ordinary person" were generally negative:

A person who is not adventurous, has no vision, and, everything they do is monotonous and a routine. ... concern too much about society... limits herself/himself to follow what is established by his/her society (Minenhle, female, 21 years old).

The ordinary people are influenced by the majority through conformity, they are afraid of telling or seeing something new, not having their own mind and etc. (Zehra, female, 18 years old).

However, there was one participant who described being ordinary as being typical, and his interpretation was neutral.

[If you are ordinary you are] neither below or above the socially accepted standard (Qumar, male, 23 years old).

One participant had mixed opinions:

Someone that follows the population. Simple, normal, safe. Being ordinary is just being typical. There is nothing wrong with being ordinary. It is good because you feel safe; less people look at your actions. It is bad because you don't stand out. No one pays attention (Alison, female, 19 years old).

\section{Turkey and home country: We have Nelson Mandela; you have Mustafa Kemal Atatürk.}

The quotes related to the comparison of the home country versus Turkey were based on cultural values or the leaders of both countries.

I come from Europe so what's ordinary there is forbidden here so I can say that we are quite different. In my country, it is more than normal to go out at night with friends, drink alcohol, and have fun (in our terms) but in Turkey, if you do that you are basically not a good girl. In my country, we tend to be quite open minded while here that's not the case. I live for the moment and go with the flow, we like the modern life, but Turkey is all based on 'religion' and old rules, that no one likes but somehow [choose/tend/have?] to follow (Luana, female 19 years old).

(...) in Turkey girls are told not to be different, don't bring attention among yourself (...) try your best to be ordinary (Alison, female, 19 years old).

From what I've gathered South Africa and Turkey to be ordinary they impose social norms that one has to complete, e.g. getting a job, getting married and having children. Uniqueness would be how successful one becomes in life because everyone has the ability to become something but to leave a legacy takes a certain type of strength. In South Africa, we have Nelson Mandela, and in Turkey, there's Mustafa Kemal Atatürk (Minenhle, female, 21 years old).

\section{Discussion}

The analyses of the accounts of seven participants across six different countries revealed the 
representations of uniqueness and ordinariness. Three major themes appeared as 'Who is unique? Extraordinary, intelligent and different', 'Ordinary: You are safe but routine' and 'Turkey and home country: We have Nelson Mandela, you have Mustafa Kemal Atatürk.' The participants mentioned the extraordinary and good attributes of individuals whom they consider to be unique. Their definitions were mostly positive. Importantly, their accounts can also be considered as the manifestation of individuality. This theme supports the accumulated literature on uniqueness, suggesting that uniqueness is unique to the Western, individualized world (e.g., Kinias et al. 2014), which might be adopted within the international community.

Furthermore, they considered uniqueness something to be achieved in time or an attribute that can be accredited only by others. Interestingly, in contrast to the individualistic attributes assigned to the unique people, having this label of being unique is dependent on others' evaluations, according to the participants. The individualistic attributes of self-reliance and selfcontainment (Vignoles et al. 2016) would not be observed with uniqueness. Moreover, considering the participants' age range, "don't know yet" approach might be associated with the development of the self.

The second theme, 'Ordinary: You are safe, but routine,' provides explanations of ordinariness. The participants' comments suggest that they consider an ordinary person either weak against the society or who plays safely. The behaviors of an ordinary person are unnecessarily under the influence of others, and their lives and experiences are restricted by and limited as compared to others. Although it might have some advantages, being ordinary is not a highly-desired attribute.

When these two themes are considered together, it is evident that regardless of the participants' cultural background, their perceptions of uniqueness and ordinariness are consistent. This interpretation may indicate that although the level of their need for uniqueness may differ from one culture to another, their definition of uniqueness is uniform.

Finally, the last theme includes a comparison using historical figures as the mean. Nelson Mandela is the legendary leader of South Africa. He fought against racism throughout his life. On the other hand, Atatürk was the leader of the independence war and the founder of the modern Turkish Republic. Associating uniqueness with respected historical figures, indicates that uniqueness is an appreciated disposition.

\section{Limitations and Future Directions}

International students are a particular group to study uniqueness with. Cemalc1lar and colleagues (Cemalc1lar et al. 2005) comment on their study with international students that the tendency to consider oneself different from one's own culture might be over-represented in this sample. Consequently, it might be worth investigating the uniqueness perception of the adults or the students who are studying in their home country, and observing if there are any differences from the international student. Lastly, cross-cultural comparisons would make more sense if they were considered with Hofstede's (2001) cultural dimensions. Especially, individualismcollectivism and indulgence-restraint dimensions might help get a deeper understanding of uniqueness. In addition to these, our study is based on brief definitions of uniqueness. Further studies might analyze uniqueness in a more profound sense with larger samples or with richer data. 


\section{REFERENCES}

Angelova M. \& Riazantseva A. (1999). “ 'If You Don't Tell Me, How Can I Know?' A Case Study of Four International Students Learning to Write the US Way". Written Communication 16/4 (1999) 491-525.

Asch S. E. (1951). "Effects of Group Pressure on the Modification and Distortion of Judgments". Ed. H. Guetzkow. Groups, Leadership and Men (1951) 177-190. Pennsylvania.

Bian Q. \& Forsythe S. (2012). "Purchase Intention for Luxury Brands: A Cross Cultural Comparison". Journal of Business Research 65/10 (2012) 1443-1451.

Brunsden V. \& Hill R. (2009). "Firefighters' Experience of Strike: An Interpretative Phenomenological Analysis Case Study". The Irish Journal of Psychology 30/1-2 (2009) 99-115.

Causse E. \& Félonneau M. L. (2014). "Within-Culture Variations of Uniqueness: Towards an Integrative Approach Based on Social Status, Gender, Life Contexts, and Interpersonal Comparison". The Journal of Social Psychology 154/2 (2014) 115-125.

Cemalcılar Z., Falbo T. \& Stapleton L. M. (2005). "Cyber Communication: A New Opportunity for International Students' Adaptation?" International Journal of Intercultural Relations 29/1 (2005) 91-110.

Cai H., Zou X., Feng Y., Liu Y. \& Jing Y. (2018). "Increasing Need for Uniqueness in Contemporary China: Empirical Evidence". Frontiers in Psychology 9 (2018) 1-7.

Conroy D. \& de Visser R. (2014). "Being a Non-Drinking Student: An Interpretative Phenomenological Analysis". Psychology and Health 29/5 (2014) 536-551.

Cope J. (2011). "Entrepreneurial Learning from Failure: An Interpretative Phenomenological Analysis". Journal of Business Venturing 26/6 (2011) 604-623.

Çetinkaya-Yıldız E., Çakır S. G. \& Kondakçı Y. (2011). "Psychological Distress among International Students in Turkey". International Journal of Intercultural Relations 35/5 (2011) 534-539.

Deutsch M. \& Krauss R. M. (1965). Theories in social psychology. New York 1965.

Griskevicius V., Goldstein N. J., Mortensen C. R., Cialdini R. B. \& Kenrick D. T (2006). "Going Along Versus Going Alone: When Fundamental Motives Facilitate Strategic (Non)conformity". Journal of Personality and Social Psychology 91/2 (2006) 281-294.

Heine S. J. \& Lehman D. R. (1997). "The Cultural Construction of Self-Enhancement: An Examination of Group-Serving Biases". Journal of Personality and Social Psychology 72 (1997) 1268-1283.

Hofstede G. (2001). Culture's consequences: Comparing Values, Behaviors, Institutions and Organizations Across Nations. California 2001.

Imhoff R. \& Erb H. P. (2009). "What Motivates Nonconformity? Uniqueness Seeking Blocks Majority Influence". Personality and Social Psychology Bulletin 35 (2009) 309-320.

Kenrick D. T., Li N. P. \& Butner J. (2003). "Dynamical Evolutionary Psychology: Individual Decision Rules and Emergent Social Norms". Psychological Review 110 (2003) 3-28.

Kim H. \& Markus H. R. (1999). "Deviance or Uniqueness, Harmony or Conformity? A Cultural Analysis". Journal of Personality and Social Psychology 77 (1999) 785-800.

Kim H. S. \& Sherman D. K. (2007). "'Express Yourself”: Culture and the Effect of Self-Expression on Choice". Journal of Personality and Social Psychology 92 (2007) 1-11.

Kim H. S. \& Sherman D. K. (2008). "What Do We See in A Titled Square? A Validation of the Figure Independence Scale". Personality and Social Psychology Bulletin 34 (2008) 47-60.

Kinias Z., Kim H. S., Hafenbrack A. C. \& Lee J. J. (2014). "Standing out as a Signal to Selfishness: Culture and Devaluation of Non-Normative Characteristics". Organizational Behavior and Human Decision Processes 124/2 (2014) 190-203.

Koca-Atabey M. (2007). "Flow Experience and Intrinsic Versus Extrinsic Motivation Among Graduate Students: An Interpretative Phenomenological Analysis". Pedagogical Research in Maximizing Education (PRIME) Journal 2 (2007) 111-121.

Koca-Atabey M. (2016). "The Representations of Disability Within Turkish Cinema (Yeşilçam): Tragic, Medical, and Ill Timed”. Ayna Clinical Psychology Journal 3/1 (2016) 16-27. 
Larkin M. \& Griffiths M. D. (2002). "Experiences of Addiction and Recovery: The Case for Subjective Accounts". Addiction Research and Theory 10/3 (2002) 281-311.

Markus H. R. \& Kitayama S. (1991). "Cultural variation in the self-concept". Eds. G. R. Goethals \& J. Strauss. Multidisciplinary Perspectives on the Self (1991) 18-48. New York.

Markus H. R., Mullally P. \& Kitayama S. (1997). "Selfways: Diversity in Modes of Cultural Participation". Ed. U. Neisser \& D. A. Jopling. The Conceptual Self in Context: Culture, Experience, Self-Understanding (1997) 13-61. Cambridge.

Milgram S. (1963). "Behavioral Study of Obedience". Journal of Abnormal and Social Psychology 67 (1963) 371-378.

O'Toole P. (2013). "Capturing Undergraduate Experience through Participant-Generated Video". The Qualitative Report 18/33 (2013) 1-14.

Palmer M., Larkin M., De Visser R. \& Fadden G. (2010). "Developing an Interpretative Phenomenological Approach to Focus Group Data". Qualitative Research in Psychology 7/2 (2010) 99-121.

Sawir E., Marginson S., Deumert A., Nyland C. \& Ramia G. (2008). "Loneliness and International Students: An Australian Study". Journal of Studies in International Education 12/2 (2008) 148-180.

Schumpe B. M., Herzberg P. Y. \& Erb H. P. (2016). "Assessing the Need for Uniqueness: Validation of the German NfU-G scale". Personality and Individual Differences 90 (2016) 231-237.

Smith J. A. (2011). "Evaluating the Contribution of Interpretative Phenomenological Analysis". Health Psychology Review 5/1 (2011) 9-27.

Smith J. A. \& Osborn M. (2003). "Interpretative Phenomenological Analysis". Ed. J. A. Smith. Qualitative Psychology. A Practical Guide to Research Methods. London (2003) 218-240.

Snyder C. R. (1992). "Product Scarcity by Need for Uniqueness Interaction: A Consumer Catch-22 Carousel?" Basic and Applied Social Psychology 13 (1992) 9-24.

Snyder C. R. \& Endelman J. R. (1979). "Effects of Degree of Interpersonal Similarity on Physical Distance and Self-Reported Attraction: A Comparison of Uniqueness and Reinforcement Theory Predictions". Journal of Personality 47 (1979) 492-505.

Snyder C. R. \& Fromkin H. L. (1977). "Abnormality as a Positive Characteristic: The Development and Validation of a Scale Measuring Need for Uniqueness". Journal of Abnormal Psychology 86 (1977) 518-527.

Sun G., Chen J. \& Li J. (2015). "Need for Uniqueness as a Mediator of the Relationship between Face Consciousness and Status Consumption in China". International Journal of Psychology 52/5 (2015) 349-353.

Tafarodi R. W., Marshall T. C. \& Katsura H. (2004). "Standing out in Canada and Japan". Journal of Personality 72 (2004) 785-814.

Takemura K. (2014). "Being Different Leads to Being Connected: On the Adaptive Function of Uniqueness in 'Open' Societies”. Journal of Cross-Cultural Psychology 45 (2014) 1579-1593.

Todd D., Simpson J. \& Murray C. (2010). "An Interpretative Phenomenological Analysis of Delusions in People with Parkinson's Disease”. Disability and Rehabilitation 32/15 (2010) 1291-1299.

Triandis H. C. (2001). "Individualism-Collectivism and Personality". Journal of Personality 69/6 (2001) 907-924.

Twenge J. M., Abebe E. M. \& Campbell W. K. (2010). "Fitting in or Standing Out: Trends in American Parents' Choices for Children's Names, 1880-2007”. Social Psychological and Personality Science 1 (2010) 19-25.

Weir H. B. (1971). Deprivation of the Need for Uniqueness and Some Variables Moderating Its Effects. Unpublished Doctoral Dissertation. University of Georgia, Georgia 1971.

Vignoles V. L., Owe E., Becker M., Smith P. B., Easterbrook M. J., Brown R. ... \& Lay S. (2016). "Beyond the 'East-West' Dichotomy: Global Variation in Cultural Models of Selfhood". Journal of Experimental Psychology: General 145/8 (2016) 966-1000.

Yamagishi T., Hashimoto H. \& Schug J. (2008). "Preferences versus Strategies as Explanations for Culture-Specific Behavior”. Psychological Science 19/6 (2008) 579-584. 